\title{
Role of engineering in sustainable water management
}

\author{
Balázs M Fekete ${ }^{1 *}$ and János J Bogárdi²
}

\begin{abstract}
The recognition of the limits of resources is almost as old as the realization that our planet is a sphere leading to concerns about sustainable resources management. Water resources in particular receive growing attention given its uneven distribution in many parts of the world. Engineering solutions to address water management challenges played significant roles in the past in areas such as access to clean water and sanitation, providing water for irrigation, offering protection against floods, allowing power generation, etc. Despite their proven benefits, engineering solutions are receiving increasing criticism due to their negative environmental and societal impacts and the high cost of their implementation and operation. More reliance on ecosystem services as an alternative is often advocated as a means to achieve more sustainable water management solutions. This paper examines key water services that human societies rely on and the feasible roles that ecosystems can play in lieu of engineering solutions. The paper applies the "balanced triangle" of the planetary (abiotic), ecosystems (biotic) and human societal (anthropic) resources and assets as a basis for evaluating different water management strategies. The ultimate goal of the paper is to offer guidance for finding a better balance in deploying ecosystem-based and engineering solutions together with satisfying the needs of human societies while minimizing the impacts on the ecosystems.
\end{abstract}

Keywords: Planetary services; Ecosystem services; Water resources management; Water supply; Waste water management; Flood control; Irrigation

\section{Introduction}

From Malthus to the Club of Rome (Ehrlich, 1968; Meadows et al., 1972) scientists have recognized the potential of reaching and possibly transgressing the Earth's limits to provide resources that satisfy the needs of human societies. Recent seminal work introducing the concept of planetary boundaries (Rockström et al., 2009a, 2009b) lists global freshwater use as one of the nine dimensions of planetary boundaries that mark potentially unacceptable environmental change, when their suggested thresholds are passed. Water resources have been on the radar of scientific awareness for several decades (Falkenmark, 1986, 1991; Postel et al., 1996), but it remained in the shadow of elevated interest in climate change.

Water is receiving more attention recently. For instance, the United Nations General Assembly declared

\footnotetext{
* Correspondence: bfekete@ccny.cuny.edu

${ }^{1}$ Corresponding author: CUNY Environmental CrossRoads Initiative, The City College of New York at CUNY, Steinman Hall Room\#188, 160 Convent

Avenue, New York, NY NY10031, USA

Full list of author information is available at the end of the article
}

2013 as the United Nations International Year of Water Cooperation (UN General Assembly 2010), inspiring a number of international conferences such as the "Water in the Anthropocene" (http://conference2013.gwsp.org) conference organized and hosted by the Global Water Systems Project, Bonn, Germany, or the "Budapest Water Summit" (http://www.budapestwatersummit.hu) initiated at the Rio +20 conference (http://www.uncsd2012.org) on sustainable development. Growing tensions between representatives from developed versus emerging economies are apparent at these international meetings regarding whether the emphasis should be on the development or on sustainability. While environmental concerns put development somewhat in the backseat in the last few decades, it is becoming increasingly clear that satisfying the needs of the unfortunate majority - who still lack access to basic services that people in the developed world take for granted - is necessary to secure a socially/politically sustainable world (Bogardi et al., 2013).

The most often quoted definition of sustainability is "development that meets the needs of the present without 
compromising the ability of future generations to meet their own needs" and was coined in the "Our Common Future" report of the World Commission on Environment and Development (Brundtland, 1987) which translates to living within the carrying capacity of our planet. A recent paper published in a special issue of the Current Opinion in Environmental Sustainability as a follow up to the aforementioned GWSP Water in the Anthropocene conference, attempted to offer a policy relevant conceptual framework to define the limits of sustainability via the balanced triangle of planetary (abiotic), ecosystem (biotic) and human societal (anthropic) resources (Bogardi et al., 2013).

The balanced triangle distinguishes resources as "assets" (or stocks) versus "services" (or fluxes) (Gleick and Palaniappan, 2010), which can serve as a means to define sustainability. Intuitively, only services (or fluxes) can be used sustainably unless the stocks are abundant beyond possible exhaustion. In the balanced triangle planetary resources (both assets such as the land, oceans, atmosphere, ores and minerals, etc.) are appropriated by both the ecosystems and human societies. Human societies also appropriate ecosystem resources, and the appropriations have feedbacks on the donor vertices (abiotic planetary or the biotic ecosystem resources) of the balanced triangle (Figure 1).

Engineering solutions offer human societies a means to bypass ecosystem services and appropriate planetary resources directly to replicate the desired service. As an example, one could consider waste water treatment that takes external energy to operate and requires building engineering infrastructure, but in return could remove water contaminants just like freshwater ecosystems do without the need to reserve vast areas to perform the said ecosystem service and with much greater efficiency due to the specific design for that particular task. In the context of a balanced triangle, one could contrast the resource utilization (including land appropriation) of both engineering and ecosystems solutions to find optimal tradeoffs.

Advocates of ecosystem solutions often omit the unaccounted "costs" of relying on ecosystems in the form of taking up land or constrains on the ecosystems capacity to deliver their services without significant degradation. Furthermore, healthy ecosystems have to sustain first and foremost their own metabolism, before providing services to human societies. From preservation of the biotic environment point of view, one could also ask if it is better to degrade the ecosystems that is inevitable when ecosystem resources are appropriated or if one should accept the "concentrated damage" that engineering solutions may impose on the environment in return for potentially leaving larger portions of the ecosystems alone with less or even without human disturbance.

This paper provides a brief overview of key water related services human societies depend on such as domestic

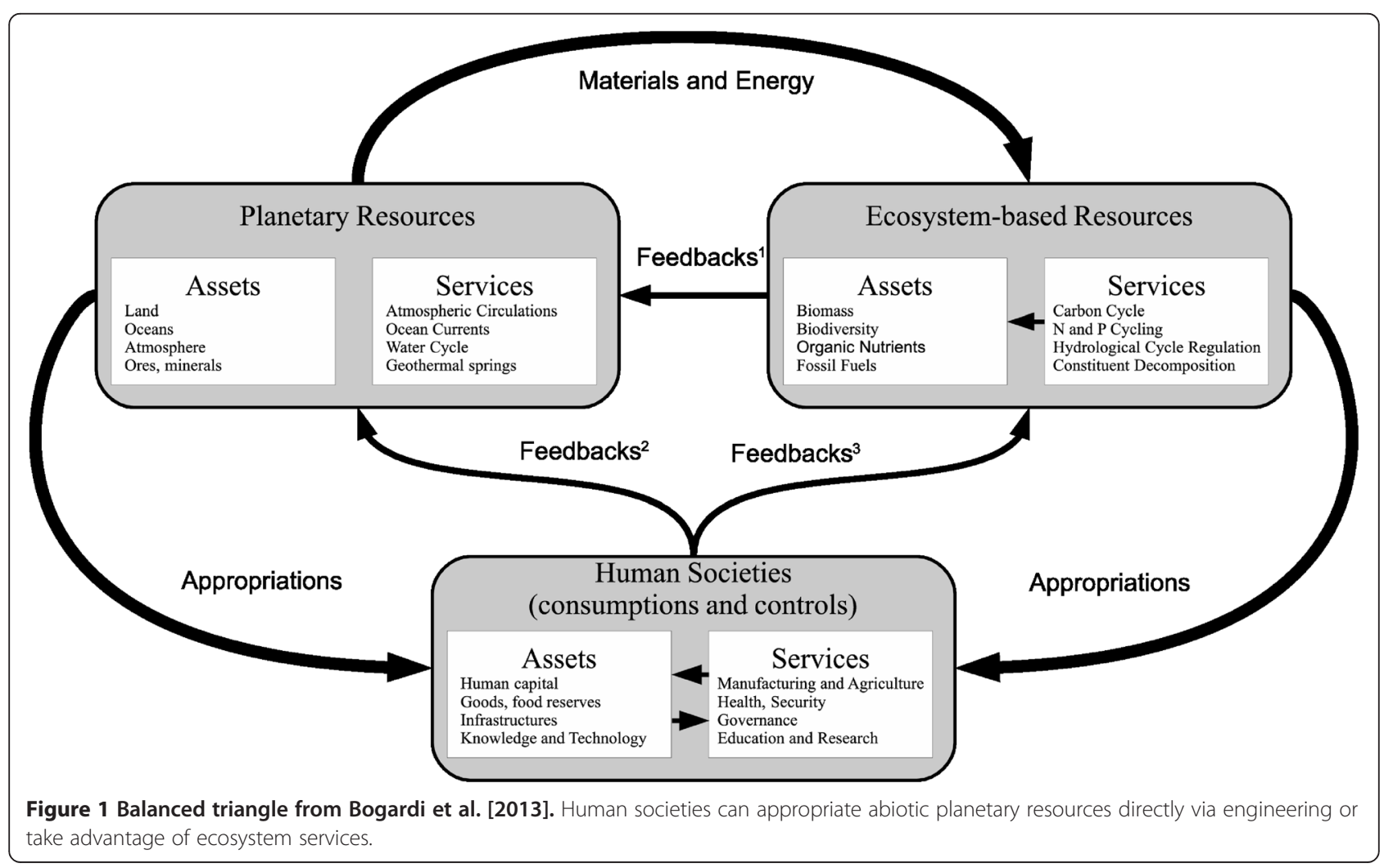


water supply, waste water management and sanitation, water storage, irrigation and flood management with respect to the role that engineering versus ecosystem solutions can play in providing these services and their impacts on planetary and ecosystem resources.

\section{Domestic water management}

Access to clean drinking water is a basic water service needed for civilized life. According to the latest joint report of the World Health Organization (WHO) and the United Nations Children's Fund (UNICEF) (WHO/UNICEF, 2010) over 884 million people have no access to improved drinking water defined as "one that, by nature of its construction or through active intervention, is likely to be protected from outside contamination, in particular from contamination with fecal matter" (http://www.wssinfo.org/definitionsmethods/introduction). An additional 2.3 billion people have no access to piped water on their premises and only 3.9 billion people have safe drinking water piped into their homes (WHO/UNICEF, 2010). Delivering domestic water to the point of consumption requires some degree of engineering since no ecosystem service could offer the mechanism to transport water to human premises.

According to the same report (WHO/UNICEF, 2010) 2.6 billion people do not use improved sanitation, out of which 1.1 billion people still defecate in the open, which could be seen as relying solely on ecosystem services for sanitation. Ancient civilizations already recognized that ecosystem solutions were inadequate, when the population density had increased and engineering solutions were needed to manage human waste (Coates-Stephens, 1998).

The history of urban sanitation can be seen as a sort of continuous "engineering failure" in the sense that engineers and urban planners repeatedly failed to foresee the consequences or rather reliably project and prepare for rapid urban growth. Engineering works were deployed retroactively in response to environmental degradation (Melosi, 2008). One could argue that it is also a continued engineering response to ecosystem services failing due to their exhaustion. The lack of sewer systems is a major source of environmental degradation and a health risk in the developing world, but combined sewer systems built throughout the developed world in anticipation that waste water can be released untreated has lead to severe water quality impairment that was later addressed by building waste water treatment facilities.

The deficiencies of combined sewer systems due to their handling of both the steady concentrated sewage and the occasional diluted high volume storm water flow and the need for separated collection of storm and waste water was recognized over a century ago (Staley and Pierson, 1899). In response to these challenges, more reliance on green infrastructures is often advocated as inexpensive alternatives to engineering work.
As an example, "The NYC Green Infrastructure Plan" (Bloomberg and Holloway, 2010) unveiled in 2010 outlined an ambitious vision to deploy cost effective green infrastructure for New York city's acute combined sewage overflow (CSO) problems. The anticipated solution is expected to reduce the projected $113 \times 10^{6} \mathrm{~m}^{3} \mathrm{yr}^{-1}$ CSO (for 2045) by $45.8 \times 10^{6} \mathrm{~m}^{3} \mathrm{yr}^{-1}$. This reduction will come from completing grey infrastructures ${ }^{\mathrm{a}}$ already planned or under construction (costing 2.9 billion USD) that will handle $21.4 \times 10^{6} \mathrm{~m}^{3} \mathrm{yr}^{-1}$ storm water. The remaining $24.4 \times 10^{6} \mathrm{~m}^{3} \mathrm{yr}^{-1}$ will be managed via a combination of additional grey infrastructure reducing CSO by $9.8 \times 10^{6} \mathrm{~m}^{3} \mathrm{yr}^{-1}$ and green infrastructure adding $14.5 \times 10^{6} \mathrm{~m}^{3} \mathrm{yr}^{-1}$ further reduction (at a combined cost of 2.4 billion USD). In other words, the green component only would contribute one third of the anticipated reduction of the storm water overflow. This green solution plan was contrasted to a grey only solution, which would reduce the combined sewage over flow only by $38.6 \times 10^{6} \mathrm{~m}^{3} \mathrm{yr}^{-1}$, where the additional grey infrastructure (beyond the already planned or under construction) would contribute $17.1 \times 10^{6} \mathrm{~m}^{3} \mathrm{yr}^{-1} \mathrm{CSO}$ reduction (at a cost of 3.9 billion USD). While the value in incorporating green infrastructures is indisputable, the bulk of the solution will still have to rely on traditional engineering. Furthermore, neither solution anticipates a full elimination of the combined sewer overflows, so one might argue that the green infrastructure plan is neither green nor a solution.

Contrasting this plan with the $1,796 \times 10^{6} \mathrm{~m}^{3} \mathrm{yr}^{-1}$ waste water that was treated by 14 treatment facilities annually, one has to conclude that the "NYC Green Infrastructure Plan" only touches the tip of the iceberg with respect to the city's waste water management and highlights the significance of operating engineering infrastructures in an urban environment. The amount of waste water treated translates to 5851 capita $^{-1}$ (based on $8,405,837$ population of the five boroughs according to the latest census estimates for 2014, http://www.nyc.gov/html/ $\mathrm{dcp} / \mathrm{html} /$ census/popcur.shtml) which is consistent with the water consumption that declined from $788 \mathrm{l} \mathrm{day}^{-1}$ capita $^{-1}$ in the mid 1980s to $476 \mathrm{l} \mathrm{day}^{-1}$ capita $^{-1}$ by 2009 (https://data.cityofnewyork.us). These numbers suggest that storm water represents the smaller portion of treated waste water (around $109 \mathrm{l} \mathrm{day}^{-1}$ capita $^{-1}$ at the most or $334 \times 10^{6} \mathrm{~m}^{3} \mathrm{yr}^{-1}$, which is three times more than the projected combined sewage over flow, assuming that all domestic waste water finds its way to the sewer system).

Putting these numbers into a hydrological perspective, the $1,796 \times 10^{6} \mathrm{~m}^{3} \mathrm{yr}^{-1}$ waste water is equivalent to $2276 \mathrm{~mm} \mathrm{yr}^{-1}$ combined waste and storm water runoff over the $789 \mathrm{~km}^{2}$ land area of the five boroughs in New York City. Based on the difference between the treated waste water and water use, we can estimate that $423 \mathrm{~mm} \mathrm{yr}^{-1}$ 
$\left(334 \times 10^{6} \mathrm{~m}^{3} \mathrm{yr}^{-1}\right.$, divided by the $789 \mathrm{~km}^{2}$ land area) is from urban runoff and the remaining $1853 \mathrm{~mm} \mathrm{yr}^{-1}$ is brought to the city as water supply from remote sources, which is almost $50 \%$ more than the annual precipitation $\left(1270 \mathrm{~mm} \mathrm{yr}^{-1}\right)$. The average runoff around New York is approximately $600 \mathrm{~mm} \mathrm{yr}^{-1}$, but due to the high proportion of impervious surfaces, the runoff in the city must be significantly higher, therefore at least one third (likely more) of the excess water leaves the city via alternative means. The planned $45.8 \times 10^{6} \mathrm{~m}^{3} \mathrm{yr}^{-1}$ new capacity to reduce CSO by 2045 translates to $58 \mathrm{~mm} \mathrm{yr}^{-1}$, which is less than $10 \%$ of the annual runoff in the region under contemporary climate.

One could argue that the unaccounted runoff that leaves the city via alternative means are a combination of planetary and ecosystem services. The distinction between planetary and ecosystem services is crucial, because the majority of the runoff is likely to leave via sheet flow, surface runoff or through groundwater flow (none of these related to any particular ecosystem).

In New York City, both the annual precipitation and the per capita water use are well above the global average (750 $\mathrm{mm} \mathrm{yr}^{-1}$ over the continental land mass (Trenberth et al., 2007) and $184 \mathrm{l} \mathrm{day}^{-1}$ capita $^{-1}$ according to FAO' AquaSTAT, respectively), where the population density is 10,700 people $\mathrm{km}^{-2}$, that is more than double the population densities of cities larger than 1,000,000 people (4500 people $\mathrm{km}^{-2}$ ). At global average water consumption (likely a very low estimate), the delivered water averaged over the city area globally is $300 \mathrm{~mm} \mathrm{yr}^{-1}$, which is similar to the annual average runoff over continents $\left(298 \mathrm{~mm} \mathrm{yr}^{-1}\right.$, (Fekete et al. 2002)). These comparisons suggest that the water delivered through the water supply tends to surpass the local runoff in most cities worldwide.

New York City prides itself for the water quality in the municipal water supply, which is accomplished by protecting the surrounding watersheds. The City of New York pays local residents to minimize industrial or agricultural activities that could adversely affect the water quality. Based on the approximately 50\% runoff ratio, the city will need to protect a minimum of twice its own area to secure its water resources. This approach might work in the wet region like the North-East Coast of the United States, but unlikely a viable solution elsewhere under drier climate regimes, where both the precipitation and the corresponding runoff ratio are much lower resulting in a quadratic increase in the watershed area that needs to be protected. For instance, in a region with similar $\left(600 \mathrm{~mm} \mathrm{yr}^{-1}\right)$ evapotranspiration as New York City but receiving $750 \mathrm{~mm} \mathrm{yr}^{-1}$ precipitation, which is the global average over the continents, the runoff ratio would drop to $20 \%$ (assuming $150 \mathrm{~mm} \mathrm{yr}^{-1}$ runoff), therefore providing the same amount of water as New
York City consumes would require more than eight times the city's area (to compensate for precipitation and lower runoff as a portion of precipitation).

\section{Agricultural water use}

The estimated amount of freshwater (both "blue" and "green" water together) used for food production (including irrigated and rain-fed crops) is $6800 \mathrm{~km}^{3} \mathrm{yr}^{-1}$ (Rockström et al., 2009a). The rationale for the inclusion of transpiration from crops as green water use is somewhat questionable (Bogardi et al., 2013) since croplands rarely replace bare impervious surfaces. As such, their water consumption should be contrasted with the "natural" water use of the ecosystems they replace. Intuitively, ecosystems tend to consume more water than managed crops since they are in equilibrium with the available water resources unlike harvested crops that may have no time to grow deep roots and could leave the land covered only by bare soil for a considerable part of the year. Only a few cultivated plants (e.g. deep rooted trees) could take up more water than the natural vegetation (Findell et al., 2006; Coe et al., 2011) unless they are irrigated. Planted eucalyptus trees in particular are known to be able to deplete shallow aquifers beyond what natural vegetations originally were able to do (Calder et al., 1997).

Accounting for green water use can be justified, if one considers water use with respect to precipitation as opposed to runoff, which is more common in water resources management. Arguably both precipitation and runoff are planetary services, although the latter is sometimes regarded as an ecosystem service despite the fact that our planet under its current climate would have a hydrological cycle irrespective of the presence of ecosystems. Undoubtedly, ecosystems play a critical role in regulating the hydrological cycle, but the dominant drivers are solar and planetary forces.

Irrigation estimated in the $1200-1800 \mathrm{~km}^{3} \mathrm{yr}^{-1}$ range (Döll, 2002; Vörösmarty et al., 2005) is regarded as the largest contributor to consumptive ("blue") water use. The actual water withdrawal is higher $\left(2500-3200 \mathrm{~km}^{3} \mathrm{yr}^{-1}\right.$ (Döll, 2002; Hanasaki et al., 2008; Wisser et al., 2010)), because a significant portion of it forms return flow and conveyance losses. Some of the return flow is the result from "over" irrigation of the crops that is necessary to avoid soil salinization, but a significant portion is from seepage throughout the conveyance canals, which is not only a water loss, but often a waste of energy that was needed for pumping.

While worldwide only $20 \%$ of agricultural lands are irrigated, their contribution to global food production is 30 40\% (Döll, 2002; Rost et al., 2008). The higher production partly comes from a combination of more intensive agriculture and a reduction of crop failures due to water shortages. Improving irrigational efficiency is largely achieved by 
more civil and agricultural engineering. Dripping or sprinkling irrigations are far more water efficient than furrow irrigation at the cost of deploying more expensive engineering infrastructures and consuming more energy.

Rainwater harvesting broadly defined as the local collection of water during the rainy season in small scale storage facilities (Ngigi, 2003; Pandey et al., 2003; Oweis and Hachum, 2006) is an ancient technique that can be dated back to the Neolithic Age (Bruins 1986). Numerous but small local reservoirs require less resources for construction and maintenance with minimal conveyance losses compared to large-scale irrigation projects (Qadir et al., 2007), but the degree to which they can offset prolonged droughts is more limited.

The alternative to irrigation is to grow more drought resistant crops (Cattivelli et al., 2008), accept crop failures time-to-time or grow crops elsewhere, where water availability is more reliable. Trading agricultural products could serve coping with crop failures (Ercin et al., 2009; Aldaya et al., 2010), but none of these alternatives utilize ecosystem services. Ecosystem services could hardly offset agricultural water demand since ecosystems are more likely to compete for water resources than offering additional sources for neighboring croplands and pastures. It has to be acknowledged however that the ecosystem service "provision of food" is frequently relied on, especially in developing countries. By collecting edible plants, leaves, roots, nuts and fruits nutritional emergencies may be offset or subsistence diets supplemented. While life saving in case of famines, gathering food directly from ecosystems is seldom the main source of calorie intake.

\section{Flood management}

Flat areas along water courses offer important benefits to its occupants including fertile soils, convenient areas for settlements, and easy access to waterways, which often outweigh the elevated risks of flood damages. The higher GDP per area in countries mostly constituted from floodplains such as The Netherlands is a testament of these benefits (APFM, 2009). Abandoning flood prone areas for human development is not a viable option irrespective of considering the sparsely populated floodplain of the Mississippi or the densely populated deltaic areas of Bangladesh (APFM, 2009), therefore balancing between development and mitigating flood disaster risks is essential in flood management.

The traditional means of flood management is to mitigate the hazard by altering the hydraulic characteristics of threatening water bodies and confining flood inundation within desired limits using engineering solutions (Van Ogtrop et al., 2005). River canalization/training was often not only driven by the desire to mitigate flood damages, but also to support navigation. The deployment of engineering works is typically problem driven and often lacked a fuller understanding of how river alteration and other anthropogenic changes on the landscape in one location altered the flow conditions elsewhere (Pielke 1999). Integrated flood management intends to address these shortcomings and consider the river basin as a whole (APFM, 2009; UNECE, 2009). Aside from paying more attention to tele-connections between engineering interventions and their impacts further downstream, the deployment of "soft" approaches in the form of more reliance on ecosystem services in flood management are frequently advocated (Silva et al., 2004; Van Ogtrop et al., 2005; Nagy et al., 2010).

Engineers in the past did not have the necessary tools and information to carry out basin-wide studies before designing engineering solutions, but by no means neglected the role of floodplains and wetlands played in flood management. The quest to find the right balance between confining rivers to narrow channelized flow via the construction of a series of dikes versus allowing flooding certain areas and offering relief in flood pressure elsewhere is just as old as flood management engineering itself. The training of the Tisza River originating in the Carpathian Mountains and flowing $1260 \mathrm{kms}$ before entering the Danube River at Titel, Serbia can serve as a prime example. In fact the Tisza is still not channelized like the Rhine or Austrian Danube where the rivers are controlled by a chain of reservoirs. The Tisza has only two major reservoirs in Hungary, none of them explicitly serving flood control. The floods generated on the foothills of the mountains where the annual precipitation is over $1000 \mathrm{~mm} \mathrm{yr}^{-1}$ can propagate rapidly to the much drier Hungarian Great Plain (where the 500 $600 \mathrm{~mm} \mathrm{yr}^{-1}$ precipitation almost matches the annual evapotranspiration). Flood waves inevitably used to inundate large areas along the lower, meandering part of the river. The desire to tame these floods dates back to the second half of the $15^{\text {th }}$ Century, but major engineering works only started in the mid- $19^{\text {th }}$ century. The main emphasis was to increase the water carrying capacity of the river by cutting off its meanders and shortening its river course. Ultimately, 115 meanders were straightened out reducing a $1419 \mathrm{~km}$ stretch of the river in 1850 to its $977 \mathrm{~km}$ length within the borders of present day Hungary (Lóczy et al., 2009).

The river regulations in the $19^{\text {th }}$ century by no means resulted in a once for all solution, but a constant endeavor to keep the river under control. Perhaps the most important long-term impact of confining the river between flood control embankments was the continuous rise of the river channel and the flood plain due to siltation (Figure 2). As a result, the Tisza no longer flows along the deepest line in its river valley similar to other regulated rivers like the Po in Italy or Huang $\mathrm{He}$ in 


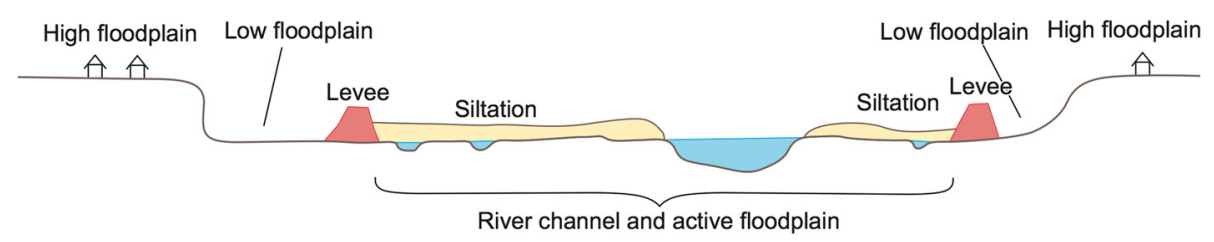

Figure 2 Rising flood control embankments.

China (Schweitzer, 2009). The steady rise of the river bed necessitated the regular expansion of flood control levees (Figure 3) (Vágás, 1982; Nagy et al., 2010).

The need for a regular revision of engineering works is not new to those who study the design of these systems. They were taught for decades, if not for over a century, that regulating rivers is not an easy task and even following the best engineering practices does not necessary lead to the desired results. The acknowledgement of the reality that river control infrastructures do not always work exactly as intended was the early realization of complex interactions between natural channel forming processes and the engineering work. The "trial-anderror" approach allowed engineers to refine their systems before they had the capabilities to carry out integrated flood management analyses.

Even the concept of a "soft" path is not new to engineers and was realized for a long time by designing the infrastructures for different flood reoccurrence frequencies. Establishing flood re-occurrence metrics from river flow observations served as a basis for differentiated flood protection. Water managers would rarely deploy the same level of efforts to prevent floods along the full length of the river, but put more emphasis on areas that have high values (human settlements, industrial developments, etc.) and possibly allow flooding less important areas (agricultural lands, forests, etc.). Engineers were taught to leave areas less protected for the very reason that wetland rehabilitation intends to achieve. One could question not only the difference between using the "ecosystem services" of wetlands versus accepting flood damages over less valued land cover types such as croplands, but the notion that flood mitigation is primarily an "ecosystem service" in the first place. Wetlands store water just as any other inundation and the primary mechanism is rather the abiotic planetary service of spreading water over the inundated
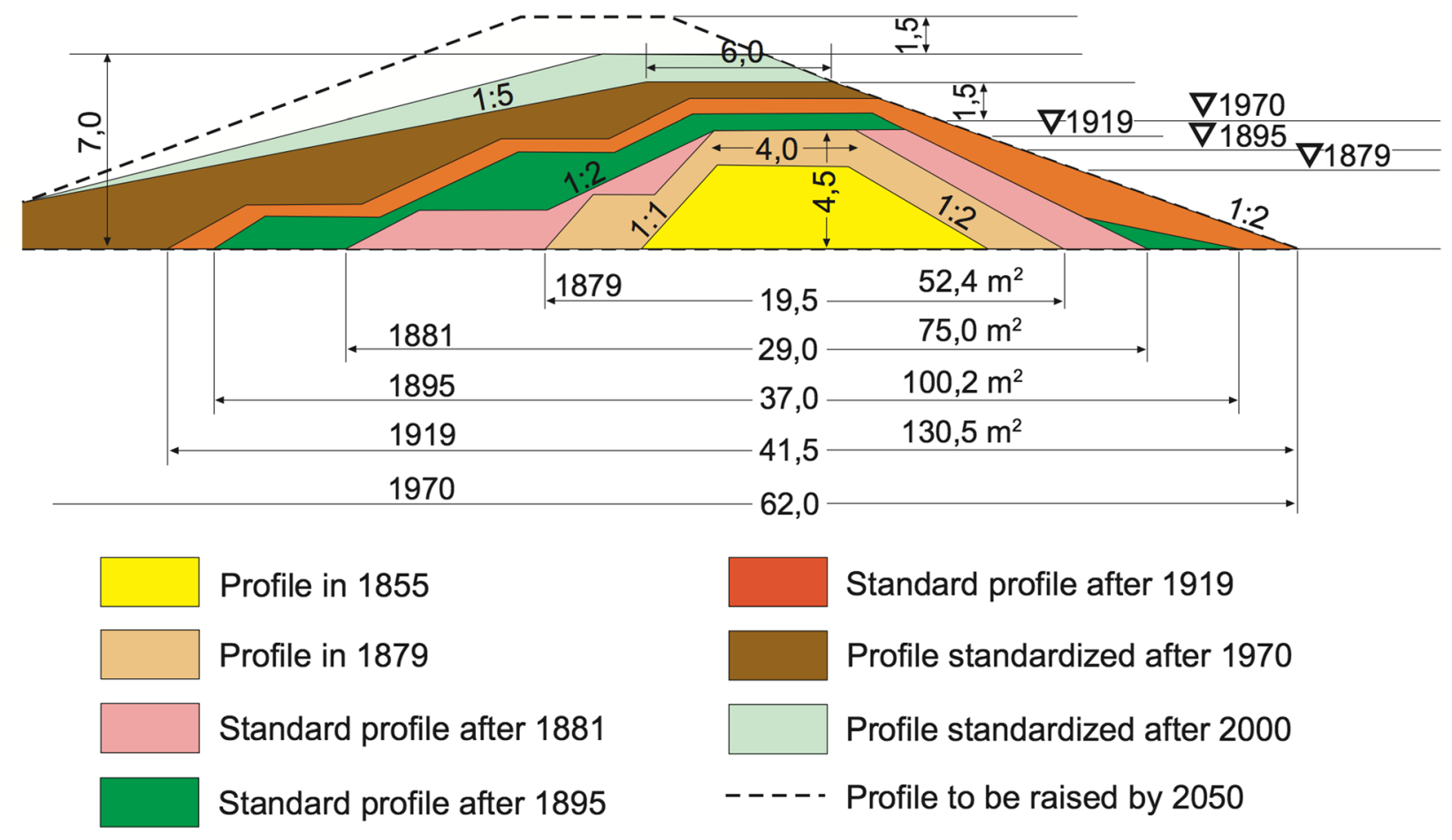

Profile in 1855

Standard profile after 1919

Profile in 1879

Profile standardized after 1970

Standard profile after 1881

Profile standardized after 2000

Standard profile after 1895

Profile to be raised by 2050

Figure 3 Embankment expansion over time along the Tisza river. 
land and hence reducing flooding levels. Forested wetlands might evaporate more water over longer periods of time, but that has less impact on the rapid raising phase of flooding although they can slow down and attenuate floods due to log jamming and debris flow.

The rising costs of flood damages are often used as a rationale to revise previous flood management practices. In reality the primary driver behind the increasing destruction is the growth of valuable assets in vulnerable areas (Barthel and Neumayer, 2011; Bouwer, 2011). Despite the increasing disaster losses in financial terms, the normalized losses with respect to the wealth of the affected population is either stagnant or declining (Neumayer and Barthel, 2011) while the losses of life are declining even in absolute terms as a result of better mitigation measures, among them mobile flood walls set up prior to the occurrence of the forecasted flood wave (Figure 4).

From a disaster risk reduction point of view, engineering flood control measures are primarily manipulating the hazard rather than mitigating vulnerability. Dikes for example prevent floods, which do not surpass the design flood to cause damage unless the dikes fail for structural reasons. Floods exceeding the design flood (thus overtopping the dikes) could lead to losses even higher than the ones which might have occurred without any flood control measure (Rother, 2014). This is due to the increased vulnerability and exposed wealth accumulated behind the dikes in anticipation of the protection provided. Through experiencing long periods without flooding the response capacity and knowledge of the population in how to deal with floods markedly decreased, thus ultimately contributing to increased disaster risk.

While dikes are essential to reduce flood risks they cannot be expected to eliminate risks forever. Awareness raising and disaster preparedness as social components are indispensable elements of sustainable flood risk mitigation. Coupled with the additional ecosystem based components of civil engineering, social preparedness and the natural retention function of landscapes reflect again the need for balanced triangle approaches.

Just like in any other ecosystem solution, setting aside wetlands for flood protection is not free in the sense that it can necessitate the human activities to move elsewhere, possibly under less favorable conditions that ultimately could take away more land from "natural" ecosystems than utilizing further the floodplains. While returning floodplains to wetlands may have other benefits beyond flood mitigation, it comes at the cost of giving up valuable land that could serve to satisfy various human needs, therefore it is more of a question of where and how to strike the right balance. Rehabilitating riverine wetlands even under moderate climatic conditions like the ones prevailing in the Upper Rhine valley in Germany could ultimately bring back malaria and other water borne diseases wiped out through the river training works in the 19th century.

\section{Summary}

Water engineering has a long history of serving human needs and is essential for civilized life. Although only the minority of mankind enjoys the full benefits of piped water, decent sanitation, irrigated agriculture supported food security or flood protection, ultimately one would hope that access to these services will be the norm for a growing number of people. While ecosystem services might play a role in complementing engineering infrastructures, the dominant means to provide a comfortable living environment for humans, especially in the ever growing urban settlements, will rest on continued use of engineering. Heavy

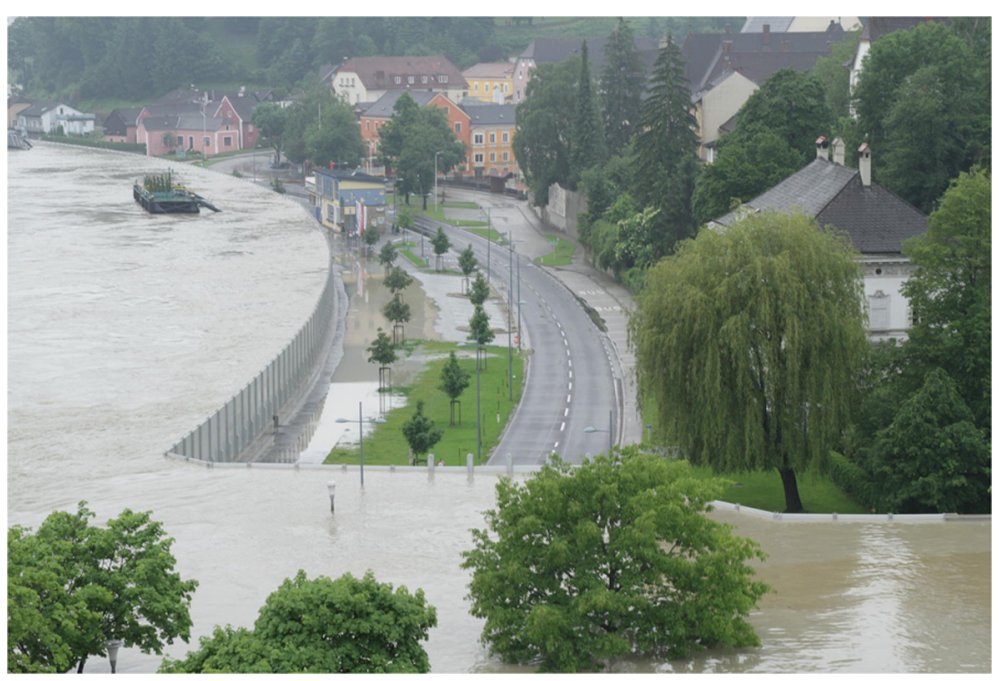

Figure 4 Mobile flood walls along the Danube river. 
reliance on ecosystem services is clearly not an option as the history of engineering shows, since the need for engineering demonstrably rose to bypass ecosystem services that could not keep up with the needs of increasing populations. Engineers are often accused of being driven by the desire "to pour more concrete on the problem", but in reality, engineering works are dominantly a response to ecosystem services' inability to scale up to meet human needs for a comfortable living space.

Perhaps it is time for a fresh look before further promoting ecosystem solutions in the name of sustainable development. For the sake of "social sustainability" one should not limit the majority of humanity from the development they desire. While ecosystems undeniably can complement engineering works, the heavy load will remain on deploying and maintaining engineering solutions all over the world. Instead of advocating infrastructures that would limit people in the developing world to achieve a comparable level of comfort that western societies take for granted, more emphasis should be put on transferring engineering knowledge and experience of what works and what failed. There is no need to let developing countries go through the same pitfalls developed countries went through. Lessons learned should be shared!

Rapid urbanization in particular in the developing world needs careful projections for long term planning. The anticipated doubling of the urban population by 2050 means that urban infrastructures will need massive extension, replacement and redesign in the next $30-40$ years. New urban agglomerations and their water infrastructures could be built in the same "ad hoc" manner as they evolved in the developed world in the $19^{\text {th }}$ and $20^{\text {th }}$ centuries resulting in legacy elements that have long lasting effects on urban planners and water engineers. Instead, the best engineering practices of today, including the incorporation of "green" infrastructure, should be looked at and future cities should be designed accordingly.

There are fortunately signs that the developing world is learning from the mistakes developed nations made in the past. China's heavy investment in wastewater treatment after 30 years of rapid economic growth could serve as an example, which already treats $47.5 \%$ of its waste water (Gao et al., 2008), while it took almost a century for the Western world on both sides of the Atlantic to take water quality seriously and clean up deteriorated surface water starting in the 1960s. Emerging economies will inevitably need to deploy more engineering solutions, therefore providing assistance to deploy them before major environmental degradations occur would be far more beneficial even from an environmental protection point of view than advocating well intended, but capacity wise limited alternatives that will ultimately constrain long-term development.

\section{Endnote}

aWe use the terms "grey" vs. "green" infrastructure to distinguish engineering and ecosystem solutions although these are not rigorous scientific terms, but widely accepted at least in the US. We recognize that using grey and green infrastructure might confuse those who are more familiar with the concepts of "grey" and "green" water (representing dilution needs for waste water disposal versus non-irrigation water use by plants respectively). To confuse the matter further, grey water is sometimes used to refer to waste water coming from showers and washing machines in contrast with "black" or "brown" water coming from toilets.

\section{Competing interests}

The authors have no competing interest with respect to the content of the presented paper. Neither Prof. Fekete nor Prof. Bogardi received any form of payment from organizations that might benefit from the funding of our paper. Neither authors own shares in companies that might benefit from the publication of this paper.

\section{Authors' contributions}

This paper is a result of numerous discussions and e-mail exchanges between the co-authors sharing similar views and concern about a number of misconceptions and an ideologically motivated framing of the sustainability questions and solutions. Our intent was to elaborate further on the balanced triangle approach presented in (Bogardi et al., 2013) and discuss the tradeoffs between exploiting planetary services directly or via ecosystem services. The fist draft of the paper was written by the lead author, which subsequently went through a number of iterations between the authors in refining and clarifying the text. Both authors read and approved the final manuscript.

\section{Acknowledgments}

The authors would like to acknowledge National Science Foundation (NSF) "EaSM: A Regional Earth System Model of the Northeast Corridor: Analyzing 21st Century Climate and Environment" grant\# EF-1049181, NSF "CNH: Impacts of Global Change Scenarios on Ecosystem Services from the World's Rivers" grant\# 1115025 and Environmental Protection Agency (EPA) STAR "Impact of Climate Change and Variability on the Nation's Water Quality and Ecosystem State" grant\# R834187 projects for providing funding.

\section{Author details}

${ }^{1}$ Corresponding author: CUNY Environmental CrossRoads Initiative, The City College of New York at CUNY, Steinman Hall Room\#188, 160 Convent Avenue, New York, NY NY10031, USA. ${ }^{2}$ Global Water Systems Project, Center of Development Research, University of Bonn, Bonn, Germany.

Received: 9 September 2014 Accepted: 31 December 2014

Published online: 12 February 2015

\section{References}

Aldaya MM, Allan JA, Hoekstra AY (2010) Strategic importance of green water in international crop trade. Ecol Econ 69(4):887-894, doi:10.1016/j. ecolecon.2009.11.001

APFM (2009) Intergrated flood managment: concept paper. World Meteorological Organization, Geneva, Switzerland

Barthel F, Neumayer E (2011) A trend analysis of normalized insured damage from natural disasters, Clim. Change 113(2):215-237, doi:10.1007/s10584-011-0331-2

Bloomberg, MR, and C Holloway (2010), NYC green infrastructure plan: A sustainable strategy for clean waterwas, planNYC, NYC Environmental Protection. http:// www.nyc.gov/html/dep/html/stormwater/nyc_green_infrastructure_plan.shtml

Bogardi JJ, Fekete BM, Vörösmarty CJ (2013) Planetary boundaries revisited: a view through the "water lens",. Curr Opin Environ Sustain 5(6):581-589, doi:10.1016/j.cosust.2013.10.006

Bouwer LM (2011) Have Disaster Losses Increased Due to Anthropogenic Climate Change? Bull Am Meteorol Soc 92(1):39-46, doi:10.1175/2010BAMS3092.1 
Bruins HJ (1986) Rainwater-harvesting agriculture for food production in arid zones: the challenge of the African famine. Appl Geogr 6(1):13-32, doi:10.1016/0143-6228(86)90026-3

Brundtland, GH (1987), Report of the World Commission on Environment and Development: Our Common Future, Oxford University Press

Calder IR, Rosier PTW, Prasanna KT, Parameswarappa S (1997) Eucalyptus water use greater than rainfall input - a possible explantation from southern India, Hydrol. Earth Syst Sci 1:249-256

Cattivelli L, Rizza F, Badeck F, Mazzucotelli E, Mastrangelo A, Francia E, Mare C, Tondelli A, Stanca A (2008) Drought tolerance improvement in crop plants: An integrated view from breeding to genomics. Field Crops Res 105(1-2):1-14, doi:10.1016/j.fcr.2007.07.004

Coates-Stephens R (1998) The Walls and Aqueducts of Rome in the Early Middle Ages, A.D. 500-1000. J Roman Stud 88:167-178

Coe MT, Latrubesse EM, Ferreira ME, Amsler ML (2011) The effects of deforestation and climate variability on the streamflow of the Araguaia River, Brazil. Biogeochemistry 105(1-3):119-131, doi:10.1007/s10533-011-9582-2

Döll, PE (2002), Global modeling of irrigation water requirements, Water Resour. Res., 38(4), doi:10.1029/2001WR000355

Ehrlich, PR (1968), Population bomb, edited by P. R. Ehrlich, Ballantine Books, United States. ISBN 1 56849-587-0, pages: 201

Ercin AE, Aldaya MM, Hoekstra AY (2009) A pilot in corporate water footprint accounting and impact assessment: The water footprint of a sugarcontaining carbonated beverage. UNESCO-IHE, Delft, the Netherlands, p 39

Falkenmark BYM (1986) Fresh Water-Time For A Modified Approach. Ambio 15(4):192-200

Falkenmark M (1991) Environment and development: Urgent need for a water perspective. Water Int 16:229-240

Fekete BM, Vörösmarty CJ, Grabs W (2002) High-resolution fields of global runoff combining observed river discharge and simulated water balances. Glob Biogeochem Cycles 16(3):1-6, doi:10.1029/1999GB001254

Findell KL, Knutson TR, Milly PCD (2006) Weak Simulated Extratropical Responses to Complete Tropical Deforestation. J Clim 19(12):2835-2850, doi:10.1175/JCLI3737.1

Gao T, Chen H, Xia S, Zhou Z (2008) Review of water pollution control in China, Frontiers of Environmental Science Engineering in China. 2(2):142-149. doi:10.1007/s11783-008-0026-8

Gleick PH, Palaniappan M (2010) Peak water limits to freshwater withdrawal and use. Proc Natl Acad Sci U S A 107(25):11155-11162

Hanasaki N, Kanae S, Oki T, Masuda K, Motoya K, Shirakawa N, Shen Y, Tanaka KK (2008) An integrated model for the assessment of global water resources - Part 1: Model description and input meteorological forcing. Hydrol Earth Syst Sci 12(4):1007-1025, doi:10.5194/hess-12-1007-2008

Lóczy D, Kis É, Schweitzer F (2009) Local flood hazards assessed from channel morphometry along the Tisza River in Hungary. Geomorphology 113(3-4):200-209, doi:10.1016/j.geomorph.2009.03.013

Meadows, DH, J. Randers, and WW Behren III (1972), The Limits to Growth, Universe Books, New York, NY, USA

Melosi MV (2008) The sanitary city, Abridgedth edn. University of Pittsburgh Press, Pittsburgh, PA, USA

Nagy I, Ligetvári F, Schweitzer F (2010) Tisza River Valley: future prospects. Hung Geogr Bull 59(4):361-370

Neumayer E, Barthel F (2011) Normalizing economic loss from natural disasters: A global analysis. Glob Environ Change 21(1):13-24, doi:10.1016/j. gloenvcha.2010.10.004

Ngigi S (2003) What is the limit of up-scaling rainwater harvesting in a river basin? Phys Chem Earth 28(20-27):943-956, doi:10.1016/j.pce.2003.08.015

Oweis T, Hachum A (2006) Water harvesting and supplemental irrigation for improved water productivity of dry farming systems in West Asia and North Africa. Agric Water Manag 80(1-3):57-73, doi:10.1016/j.agwat.2005.07.004

Pandey DN, Gupta AK, Anderson DM (2003) Rainwater harvesting as an adaptation to climate change. Current 85(1):46-59

Pielke RA Jr (1999) Nine fallacies of floods, Clim. Change 42:413-438

Postel SL, Daily GC, Ehrlich PR (1996) Human appropriation of renewable fresh water. Science 271(2):785-788

Qadir M, Sharma BR, Bruggeman A, Choukr-Allah R, Karajeh F (2007) Non-conventional water resources and opportunities for water augmentation to achieve food security in water scarce countries. Agric Water Manag 87(1):2-22, doi:10.1016/j.agwat.2006.03.018
Rockström J, Steffen W, Noone K, Persson A, Chapin FS, Lambin EF, Lenton TM, Scheffer M, Folke C, Schellnhuber HJ (2009a) A safe operating space for humanity. Nature 461(7263):472-475

Rockström, J et al. (2009b), Planetary Boundaries: Exploring the Safe Operating Space for Humanity, Ecol. Soc., 14(2):32

Rost S, Gerten D, Bondeau A, Lucht W, Rohwer J, Schaphoff S (2008) Agricultural green and blue water consumption and its influence on the global water system. Water Resour Res 44(9):1-17, doi:10.1029/2007WR006331

Rother, KH (2014), Zur Abschätzung des Restrisikos hinter Hochwasserschutzanlagen unter sich verändernden gesellschaftlichen Randbedingungen, Korresp. Wasserwirtsch., 7(11)

Schweitzer F (2009) Strategy or Disaster: Flood Prevention Related Issues and Actions in the Tisza River Basin. Hung Geogr Bull 58(1):3-17

Silva W, Dijkman JPM, Loucks DP (2004) Flood management options for The Netherlands. Int J River Basin Manag 2(2):101-112, doi:10.1080/ 15715124.2004.9635225

Staley C, Pierson GS (1899) The Separate System of Sewerage, Its Theory and Construction. Van Nostrand, New York, NY, USA

Trenberth KE, Smith L, Qian T, Dai A, Fasullo J (2007) Estimates of the Global Water Budget and Its Annual Cycle Using Observational and Model Data. J Hydrometeorol 8(4):758-769, doi:10.1175/JHM600.1

UN General Assembly (2010) International Year of Water Cooperation. www.un. org/ga/search/view_doc.asp?symbol=A/RES/65/154

UNECE (2009) Transboundary flood risk management. United Nations, Geneva, Switzerland

Vágás I (1982) A Tisza árvizei (Floods of the Tisza River). VÍZDOK, Budapest

Van Ogtrop, FF, AY Hoekstra, and F. van der Meulen (2005), Flood management in the lower incomati river basin, Mozambique: Two alternatives, J. Am. Water Resour. Assoc., (June), 41(3):607-619

Vörösmarty CJ, Leveque C, Revenga C, Caudill C, Chilton J, Douglas EM, Meybeck M, Prager D (2005) Fresh Water, in Ecosystems and Human Well-being: Current States and Trends. In: Hassan R, Scholes R, Ash N (eds) Millennium Ecosystem Assessment, Volume 1: Condition and Trends Working Group Report. Island Press, Washington, DC

WHO/UNICEF (2010) Progress on Sanitation and Drinking Water. World Health Organization and UNIFCEF, Switzerland Geneva

Wisser D, Fekete BM, Vörösmarty CJ, Schumann AH (2010) Reconstructing 20th century global hydrography: A contribution to the Global Terrestrial Network- Hydrology (GTN-H). Hydrol Earth Syst Sci 14(1):1-24, doi:10.5194/hess-14-1-2010

\section{Submit your manuscript to a SpringerOpen ${ }^{\circ}$ journal and benefit from:}

- Convenient online submission

- Rigorous peer review

- Immediate publication on acceptance

- Open access: articles freely available online

- High visibility within the field

- Retaining the copyright to your article

Submit your next manuscript at $>$ springeropen.com 